\title{
THE IMPLEMENTATION OF INFORMATION AND COMPUTER TECHNOLOGIES IN THE PROCESS OF FORMATION OF PROFESSIONAL COMPETENCIES OF FUTURE SPECIALISTS-MUSICIANS
}

У статmі розглядається питання впливу інформаційно-комунікаційних технологій (далі - IKT) на розвиток професійних компетентностей майбутніх фрахівцівмузикантів. Різні аспекти цієї проблеми визначаються з точки зору актуальності в рамках сучасної мистецької освіти. Досліджуючи особливості впровадження IKT у вищу музичну освіту, ми зазначили основні законодавчі акти, якими регулюється плинність цього процесу на території України а також вказані основні підходи до визначення питання ролі ІКT в сучасній музичній освіті із виділенням теоретичних аспектів щодо вказаної проблеми.

Враховуючи досліджену літературу, у роботі вказані основні способи використання інформаційно-комунікаційних технологій у процесі навчання з урахуванням специфріки окремих закладів вищої освіти. Окремо зазначене місие мультимедійних технологій в рамках навчального процесу на базі сучасних осередків вищої музичноі освіти, відповідно дослідження впливу ІКТ на процес фрормування фрахових компетент ностей студентів-музикантів. Також розглянута проблема невизначеності питання щодо остаточного тлумачення поняття мультимедійних засобів навчання у сучасній психолого-педагогічній науці, що свідчить про актуальність дослідження цієї проблеми в сучасній музичній педагогіці та пояснюється ситуаційністю використання згаданого вище поняття.

У дослідженні наведена класифікація мультимедійних технологій в рамках музичноі освіти з урахуванням якостей та ознак окремого програмного забезпечення на шляху фрормування фрахових компетентностей студентів. Зокрема, надається перелік спеціальних комплексів навчального спрямування, з урахуванням яких були зазначені відповідні найменування програмного забезпечення, що відповідають тій чи іншій категорії. Відповідно інтеграція різних мультимедійних технологій в освітній процес сприяє формуванню спеціальних орахових компетентностей прооресійного музиканта-виконавця у майбутньому. В межах дослідження надана характеристика та проаналізована специфіка різного програмного забезпечення, діючого в рамках сучасної мистецькоі освіти, а також в умовах дистанційного навчання.

Ключові слова: IKT, мультимедійні технології, інформатизація, професійні компе- тентності, фрахівець-музикант, музична ocвima.

The article considers the impact of information and communication technologies (ICT) on the development of professional competencies of future specialists-musicians. Various aspects of this problem are determined in terms of relevance in modern art education. Investigating the features of the introduction of ICT in higher music education, we have identified the main legislation governing the flow of this process in Ukraine and the main approaches to determining the role of ICT in modern music education with the outlining of theoretical aspects of this problem. Taking into account the investigated literature, the paper identifies the main ways of using the information and communication technologies in the learning process taking into account the specifics of individual institutions of higher education.

Moreover, the article highlights the place of multimedia technologies in the educational process within the modern centres of higher music education according to the investigation of the impact of ICT on the process of formation of professional competencies of studentsmusicians. The problem of uncertainty in the final interpretation of the concept of multimedia teaching aids in modern psychological and pedagogical science which evidences the relevance of investigation of this problem in modern musical pedagogics is considered seperately. In the course of the research, the classification of multimedia technologies in the framework of music education is given, taking into account the qualities and characteristics of individual software on the way to the formation of professional competencies of students. The article gives the list of special complexes of educational orientation, due to which the corresponding names of the software complying with this or that category have been specified. Accordingly, the integration of various multimedia technologies into the educational process contributes to the formation of special professional competencies of a professional musician-performer in the future. The study provides a description and analysis of the specifics of various software operating in modern art education, as well as in the context of distance learning.

Key words: ICT, multimedia technologies, computerization, professional competencies, specialist- musician, music education.
Постановка проблеми в загальному вигляді. Всеохоплюючі процеси розвитку сучасного суспільства в напрямі технічного прогресу зумовлюють постійний розвиток усіх сорер його існування.
Не оминають подібні тенденції й сучасну освіту, яка нині досить впевнено, швидкими темпами рухається в бік високого рівня інфрорматизації. Розглядаючи питання «осучаснення» вищої освіти 
слід розуміти, що за останні роки рівень інфрормаційної обізнаності серед населення підвищився в геометричній прогресії, що змусило вже на цьому етапі привнести суттєві зміни до навчального процесу, поступово корегуючи методики та концепції навчання на базі освітніх закладів.

Вища мистецька освіта наразі $€$ гарантом забезпечення якісних умов набуття майбутніми фрахівцями професійних компетентностей відповідного рівня для подальшої інструментально-виконавської, вокально-виконавської або музично-педагогічної діяльності. Крім того, загальний рівень розширення інфрормаційного простору вимагає на сьогодні від компетентного фрахівця у галузі музичного мистецтва високого рівня володіння інфрормаційно-комунікаційними технологіями (далі - IKT), засобами мультимедіа та іншими сучасними комп'ютерними технологіями, які вже стали необхідними у процесі навчання студентів, як інструмент ефрективного засвоєння знань, умінь й навичок.

Проблема інтеграції IKT у навчальний процес так чи інакше виступає як чинник ефективного навчання на стадії сучасного розвитку освіти та в умовах актуальної ситуації у світі, гарантуючи можливість навчання, спрощуючи засвоєння інорормації та пропонуючи відмінні від традиційних, більш наочні методи та методики проведення занять із теоретичних або практичних дисциплін.

Аналіз останніх досліджень і публікацій. Нині в рамках педагогіко-психологічних досліджень і науково-методичних розробок питання впровадження IKT у навчальний процес розглянуте в досить широкому спектрі. Значний прошарок наукових знань шодо цієї проблеми висвітлений у роботах О. Співаковського [13], М. Кадемії, Ю. Шахіної [7], Л. Петухової [10], Ю. Рамського [12], В. Мадзігон, В. Лапінського, Ю.Дорошенко [8], Н. Бойко, О. Воронкіна, С. Літвінчук, Н. Ничкало. Питання інтеграції інфрормаційно-комунікаційних технологій у музичну освіту на всіх її рівнях, розвиток фахових компетентностей студентів-музикантів в умовах впровадження IКT досліджені у роботах Н. Бєлявіної [1], Л. Варнавської [2], Л. Гаврілової [3; 4; 5], Ю. Олійника [9], О. Чайковської, Г. Александрової [14], Д. Чуракова [15], В. Бовко, В. Варейчук, Д. Пильгуй, К. Фадєєва, В. Хоменко, О. Целих, Т. Турчин.

Виділення не вирішених раніше частин загальної проблеми. У процесі дослідження наукової літератури за відповідною темою було визначено, що існуючі підходи до питання інтеграції IKT в музичну освіту висвітлені не в повній мірі. Поза увагою дослідників залишаються питання доцільності застосування тих чи інших мультимедійних технологій у процесі фрормування фрахових компетентностей студентів-музикантів, дослідження існуючого спектру IKT, які використовуються чи можуть використовуватися в рамках навчального процесу, а також їхня спрямованість на фрормування предметних срахових компетентностей у процесі вивчення тих чи інших дисциплін.

Мета статті полягає в дослідженні ролі IKT в рамках сучасної мистецької освіти як позитивного чинника фрормування професійних компетентностей студента-музиканта.

Виклад основного матеріалу. Формування просресійних компетентностей майбутнього фахівця музичного мистецтва - складний багатогранний процес, який потребує сприятливого впливу багатьох чинників. В умовах розширення поля інфрорматизації усіх сорер життя людини, інорормаційно-комунікаційні технології активно інтегруються в цей процес, безпосередньо впливаючи на нього.

На території України згаданий вище процес інфрорматизації освіти діє на базі чинних Законів «Про основні засади розвитку інфрормаційного суспільства в Україні на 2007-2015 роки», «Про інноваційну діяльність», «Про національну програму інфрорматизації»». Після впровадження відповідних законів у науковий обіг був успішно впроваджений термін, відомий як «інформаційне середовище». На основі усіх нововведень IКТ поступово інтегрувалися в усі рівні освітнього процесу - від початкової до вищої.

Ступінь дослідженості проблеми впровадження інорормаційно-комунікаційних технологій у вітчизняній педагогіці дозволяє розглянути кілька підходів щодо цього питання з позицій поглядів окремих вчених. Так, на думку Д. Чуракова [15], IKT сприяють розвитку рівня творчої різноманітності серед студентів спеціальностей мистецького напряму, що мотивує їх до подальшої самореалізації, допомагають у розробці та створенні принципово нових музично-освітніх систем на базі актуальних інформаційно-технологічних здобутків.

Враховуючи вказане, зміст подобної фрорми освіти складатимуть такі теоретичні аспекти:

1. Нові форми проведення основних і спеціальних дисциплін, які змогли б забезпечити різнопланові зв'язки на перетині художньої та інформаційної компетентностей.

2. Оптимізація освітніх умов, зокрема створення спеціального комплексу професійного, а також навчального напряму та інфрормаційно-технологічних нововведень.

3. Процес становлення та фрормування базових вмінь і навичок, які сприяють гармонійному розвитку особистості [12].

Ю. Олійник визначає необхідність об'єднання та поступової інтеграції ІКТ з традиційними методиками навчання, що стосуються обробки-осмислення слухової, зорової, а також тактильної інфрормації, її більш досконалого застосування в навчанні, а в подальшому - у фаховій діяльності. 
Дослідник наголошує на обов'язковій необхідності фокусуванню уваги на створення й подальше формування у студентів-музикантів комплексу інформаційно-технологічних а також мистецькометодичних компетентностей. Зокрема, він виділяє три основні способи використання інформаційно-комунікаційних технологій під час освітнього процесу:

1. Профресійний (комплексно-інтегративний) спосіб залучення ІКТ як професійного інструмента фахівця музичного мистецтва.

2. Комунікативний (програмно-адаптивний) комунікація з будь-якими зовнішніми суб'єктами шляхом використання IKT.

3. Розробницький - спрямований на фрормування та розробку нових фрорм і методів застосування та використання IKT, створення умов для сприятливого творчого та робочого середовища 3 метою досягнення встановлених задач, випробувань і спеціальної експертної оцінки комп'ютерних, мультимедійних та інших засобів.

Відомо, що процес інфрорматизації - створення та розповсюдження або ж оптимізація вже існуючого програмного забезпечення під умови навчального процесу нині займає пріоритетні позиції в сучасній вищій освіті, як і загальна мультимедизація освітнього середовища. В розрахунок завідома брався той фракт, що подібні трансорормації якісним чином вплинуть на хід навчального процесу, підвищуючи продуктивність і швидкість оволодіння студентами базовими компетентностями у процесі здобування освіти.

До того ж, слід звернути увагу на розповсюдженість і відсутність кінцевої визначеності такого поняття як «мультимедійні освітні технології». Деякі дослідники надають цьому визначенню відмінних рис і навіть змінюють фрормулювання залежно від умов його використання. Так, згаданий вище термін у педагогіці зустрічається як «електронні навчальні видання», «комп'ютерноорієнтовані навчальні засоби», «мультимедійні засоби навчання» [4, с. 154]. В рамках цього дослідження поняття мультимедійних технологій у мистецькій освіті трактується як комплекс актуальних засобів навчального спрямування, побудованих на основі технологій мультимедіа з метою збільшення результативності та ефрективності процесу формування фрахових компетентностей.

Нині відомо, що сучасні IKT забезпечують вільне поєднання наукових технологій інформаційно-комунікативного спрямування 3 традиційно творчими для мистецьких фракультетів методами навчання, що дозволяє майбутнім фрахівцям-музикантам отримувати знання та засвоювати матеріал більш різнобічно й продуктивно. Розглядаючи питання інфрорматизації мистецької освіти на міжнародному рівні, можна зауважити, що досвід закордонних колег за період останніх 10 років втілився у процес фрормування і виокремлення самостійного напряму - музично-комп'ютерні технології [5].

Поряд із подібними нововведеннями за кордоном вітчизняна мистецька освіта також увібрала в себе деякі технологічні нововведення, які вдало інтегрувалися в рамки навчального процесу або ж використовуються студентами під час їхньої самостійної роботи чи досліджень проблемних питань. Якщо звернутися до питання класифікації різноманіття існуючих у музичній освіті ІКТ, спрямованих на формування профресійних компетентностей, то всі інтегровані мультимедійні технології можна упорядкувати за принципом відмінності якостей і ознак. Подібну класифрікацію можна здійснити з точки зору розгляду певного напряму музичного мистецтва у складі музичного виконавства, музичної творчості, прослуховування музичних творів, отримання теоретичних знань або відомостей історичного характеру. Використання класиорікації такого типу утворює певну кількість комплексів навчального спрямування в рамках музичної освіти, а саме:

1) комплекс практичного відпрацювання навичок гри на основному / спеціальному / додатковому музичному інструменті із залученням відповідних програм;

2) комплекс розрахований на розвиток й актуалізацію закріплених знань, в рамках якого традиційні методи доповнюють програмні засоби (для пояснення окремих теоретичних питань), електронна література, проводяться зрізи знань теоретичного спрямування (доцільний для застосування у процесі опанування групових дисциплін музичнотеоретичного циклу, теоретичних частин виконавських дисциплін, таких як «Оркестр», «Хор», «Ансамбль», «Диригування»);

3) для розвитку музичного слуху використовують комплекс програм-тренажерів, які забезпечують різні рівні перевірки музичного слуху, містять диктанти різного рівня складності, дозволяють тренувати правильне визначення гамм, інтервалів, акордів, дозволяють розвивати правильне вокальне інтонування;

5) комплекс тренування й засвоєння знань історико-мистецького напряму, що включає в себе різні електронні ресурси, зокрема, довідникові джерела з прикріпленими аудіофайлами або ж відео-фрагментами, музичні енциклопедії [4, с. 164-165].

Враховуючи те, що кількість програм, які дозволяють сприяти розвитку фрахових компетентностей музикантів, є значною, у досліджені пропонуються найбільш розповсюджені програми, які користуються попитом в рамках музично-освітнього процесу. Як прикладу програм першого комплексу можна навести програму “Yousician”, за допомогою якої студенти-гітаристи мають змогу відпрацьовувати технічні прийоми різних рівнів 
складності й стилістичних напрямів, використовуючи при цьому табулатурний тип музичної нотації, який вважається найбільш давнім видом графрічного запису музичних творів (відомим із XVI ст.), більш простим для сприйняття порівняно із традиційною нотацією та користується більшим попитом серед початківців-аматорів.

У нагоді студентам-музикантам, які тільки опановують інструмент фрортепіано в рамках дисципліни «Загальне фрортепіано», можуть стати програми "Simply Piano", "Flowkey", "Piano Marvel", "Chordana play", "Piano tuttorial", які розраховані на рівень піаністів-початківців, допомагають закріпити навички гри на інструменті у самостійній підготовці до занять. Вони призначені для встановлення на комп'ютер, телефон, планшет. Програми використовуються одночасно із грою на фрортепіано, розпізнають звуки виконуваних творів, корегують помилки, містять відео-уроки навчального матеріалу, розташованого за принципом від простого до складного. Деякі з програм мають корисні фрункції: транспозиція, темпова і динамічна градація, оцінювання результату - і це далеко не повний їх перелік.

Можна стверджувати, що використання вказаних вище програм сприяє розвитку такої фрахової компетентності студентів-музикантів, як «демонстрація рівня музично-виконавської майстерності», а також «можливості свідомим чином об'єднувати й застосовувати сучасні інновації у поєднанні зі світовими традиціями у виконавстві, музикознавстві та музичній педагогіці» [11, с. 7]. Але потрібно враховувати, що в питанні розвитку фрахових компетентностей виконавців-піаністів і виконавців на інших інструментах академічного напряму подібні програми не можуть забезпечити належний рівень профресійного розвитку та зростання спеціальних вмінь і навичок.

До програм, показових для другого та четвертого комплексу, які дозволяють посилити рівень наочності та підвищити зацікавленість студентів, а також збільшити інфрормаційну місткість в рамках навчальних занять, належить Microsoft Power Point - комп'ютерна програма, яка дозволяє створювати презентації (ряд слайдів із зображенням, певною кількістю текстової інформації, звуковим або ж відеорядом) та у комбінації із мультимедійним проектором зображення дозволяє викладати певну кількість структурованого матеріалу, насиченого образною та значеннєвою інфрормацією. Доцільно використовувати цю програму для створення презентацій до лекційних і практичних занять із музично-теоретичних дисциплін («Історія музики», «Теорія музики», «Гармонія», «Поліфонія», «Аналіз музичних фрорм»).

В умовах епідеміологічної ситуації, коли навчальний процес все більше перебазовується на дистанційний рівень, ІКТ як ніколи відіграють украй важливу роль для розвитку професійних компетентностей для майбутніх фрахівців мистецького напряму (виконавців і педагогів). Мультимедійні технології дають змогу студентам засвоювати нові знання, тренувати вміння та навички у режимі онлайн без суттєвих інформаційних втрат. Така ситуація призводить до швидких темпів ще глибшої інтеграції ІКТ у навчальний процес на базі мистецьких фракультетів.

Програми Google Meet, Zoom та Skype зробили можливим проведення навчальних занять в умовах дистанційного навчання, поєднуючи в собі можливості одночасного передавання голосу та зображення (в Google Meet, Zoom - можливості двосторонньої демонстрації екрана). Подібний фрормат відеоконореренцій значно оптимізує процес дистанційного навчання (особливо при високоякісному інтернет-зв'язку). Досить розповсюдженою стала і практика використання цих програм з метою проведення виступів на залікових іспитах з основного або спеціального музичного інструменту, вокального мистецтва, проведення творчих концертів, що дозволяє значною мірою реалізовувати творчі здібності студентів-музикантів і продемонструвати рівень оволодіння фраховими компетентностями.

Вказані IKT сприяють процесам фрормування фахових компетентностей, які безпосередньо пов'язані з можливістю здійснення менеджерської, редакторської, лекторської (Power Point та Google Classroom), аранжувальної, звукорежисерської та інших видів діяльності у сфері музичного мистецтва; здатністю застосовувати традиційні, а також альтернативні інформаційно-комунікаційні технології музикознавчого, виконавського, композиторського та диригентського знання. За допомогою згаданих мультимедійних технологій майбутній фахівець має змогу оволодіти фраховою компетентністю, пов'язаною зі здатністю усвідомлювати тонку художньо-естетичну природу музичного мистецтва, а також отримати «здатність застосовувати ключові знання щодо провідних музичних систем чи концепцій», «збирати, аналізувати, синтезувати художню інформацію та застосовувати їі в процесі практичної діяльності» [11, с. 7].

Прикладами програм другого та четвертого комплексу $є$ використання навчальних платорорм Google Classroom та Moodle (менш розповсюджені), які дозволяють здобувачам мистецької освіти у повній мірі виконувати всі поставлені перед ним завдання спеціального й загального характеру у формі опитування, тестування, завдання відкритого типу, опрацювання нотного матеріалу, перегляд відео- чи прослуховування аудіо-матеріалів. Наприклад, Google Classroom дозволяє розробляти планування щодо проведення й перевірки завдань, відносно навчальної програми.

щодо програм-тренажерів для розвитку музичного слуху, то можна виокремити програму 
"Transcribe", яка користується попитом у багатьох музикантів-виконавців як головний інструмент-помічник для «знімання» музичного твору за допомогою слуху, програму "EarMaster" - основне завдання якої полягає у тренуванні слуху користувача шляхом вправ на визначення інтервалів, нот і звукорядів. Результативним є задіяння цих програм у курсі дисципліни «Сольфеджіо».

До ІКТ, які використовуються в рамках вказаної вище класифікації, відносяться програми "Sibelius", "Magic Score Maestro", які студенти можуть використовувати для створення та виконання навчальних творів і вправ у різних жанрах і стилях, аранжувань і партитур для сольних інструментів, ансамблів, оркестрів, їх звукове відтворення, а також потужного редактора для корегування нотного тексту. Широкого розповсюдження й популярності вказані програми, враховуючи широкий спектр можливостей, отримали в рамках викладацьких колективів. Серед основних переваг програми в рамках інфрорматизації мистецької освіти можна зауважити значне полегшення навчального процесу, самостійного навчання та виконання творчих завдань в рамках постійного ії̈ використання як студентами, так і викладачами.

Поряд із "Sibelius" та "Magic Score Maestro" свою освітню й допоміжну фрункції виконує програма "Discord", яка вважається своєрідним винятком серед типових мультимедійних засобів навчання, оскільки це програмне забезпечення було створене для групового спілкування та здобуло неабияку популярність серед геймерів. Але виключно у цій програмі як інструмента для комунікації під час проведення занять із дисципліни «Сольсреджіо» $€$ змога досягти гарного рівня балансу звучання голосів, чого не дозволяють технічні можливості інших подібних програм. Без сумніву, ці програми залучають до взаємодії міждисциплінарні зв'язки і в змозі допомогти формуванню здатності здійснювати аранжувальну, редакторську, творчо-продуктивну (композиторську) діяльність, застосовувати набуті знання на практиці [11, с. 7].

Важливим чинником у проблемі інтеграції IKT у мистецько-освітній простір є фрормування виконавської майстерності майбутнього фахівця-музиканта - провідного виду діяльності у галузі музичного мистецтва, який безумовно має найвищий статус в рамках френомену художньо-виконавської інтерпретації. Як зазначають у публікації «Творчий розвиток майбутнього педагога-музиканта у процесі художньої інтерпретації вокальних творів» науковці Н.О. Гунько, А.О. Чехуніна [6], орормування вміння «створювати та реалізовувати власні художні концепції у виконавській діяльності» [11, с. 7], тобто інтерпретації (вокальні, інструментальні, диригентські), повинно спиратися на вивчення та аналізування різних виконавських модисрикацій авторського задуму, що може бути можливим завдяки доступу до інтернет-мережі та, наприклад, сайту YouTube, де зберігаються численні виконавські версії творів.

Вказані вище програми здатні досить помітно збільшити професійний спектр знань, вмінь і навичок майбутнього фрахівця-музиканта, за допомогою додаткової локалізації, активізації «апарату» сприйняття особистості, пожвавити увагу й мислення, рівень музичного інтелекту, уміння систематизувати отриману інорормацію, розвиток та вдосконалення музичного слуху, навички професійного управління процесами вивчення та подальшого накопичення фрахових термінів [5]. Крім того, дослідниками визначено, що використання IKT у вищих навчальних закладах мистецького спрямування за статистикою суттєво активізує рівень періодичної наукової й дослідницької діяльності серед студентства. Комунікаційні технології мультимедійного зразка активізують формування фахових компетентностей у напрямі виявлення та аналізу культурно-історичних явищ, творчо-пошукової роботи, наукових досліджень.

Висновки. 3 огляду на зазначене, можна визначити, що загальна інформатизація мистецької освіти, як і багатьох інших галузей, покликана перебувати в ролі певного фрактору мотивації та професіоналізації знань, вмінь і навичок кожного майбутнього фрахівця-виконавця, але водночас абсолютно не припускає поступової зміни живого викладача на один або ж сукупність засобів ІКТ, а лише прагне «до створення середовища, яке надає майже необмежені можливості для використання IКТ як студентами, так і профресорськовикладацьким складом для повного задоволення їх інтелектуально-профресійних потреб» [13, с. 2].

\section{БІБЛІОГРАФІЧНИЙ СПИСОК:}

1. Бєлявіна Н.Д. Деякі методичні проблеми використання нових комп'ютерних технологій у музичній освіті. Культура і мистецтво в сучасному світі: Наукові записки КДУКіМ. Київ : КДУКіМ, 1998. Вип. 1. C. 195-201.

2. Варнавська Л.І. Формування готовності студентів до використання комп'ютерних технологій на уроках музики. Педагогіка вищої та середньої школи. 2013. Вип. 38. С. 11-15. URL: https: //journal.kdpu.edu.ua/ped/article/view/3101 (дата звернення: 15.03. 2020).

3. Гаврілова Л., Федоришин В. Проблема фрормування професійної компетентності майбутніх вчителів музики засобами комп'ютерних технологій у теорії вітчизняної музичної освіти. Профресіоналізм педагога: теоретичні й методичні аспекти. 2017. Вип. 5(1). С. 213-225. URL: http://nbuv.gov.ua/UJRN/ prptma_2017_5(1)_22 (дата звернення: 14.03.2020).

4. Гаврілова Л.Г. Система формування професійної компетентності майбутніх вчителів музики засобами мультимедійних технологій : дис. д-ра пед. наук: 13.00.04 / Нац. пед. ун-т ім. М.П. Драгоманова. Київ, 2015. 656 с. URL: https://npu.edu.ua/images/ 
file/vidil aspirant/dicer/D 26.053.01/dis Gavrilova.pdf (дата звернення: 28.02.2020).

5. Гаврілова Л.Г. Формування профресійної компетентності майбутніх вчителів музики засобами мультимедійних технологій : монографія. Київ : Видавництво НПУ ім. М.П. Драгоманова, 2014. 403 с.

6. Гунько Н.О., Чехуніна А.О. Творчий розвиток майбутнього педагога-музиканта у процесі художньої інтерпретації вокальних творів. Педагогіка фрормування особистості у вищій і загальноосвітній школах. 2020. № 70, т. 1. С. 191-195.

7. Кадемія М.Ю., Шахіна І.Ю. Інформаційно-комунікаційні технології в навчальному процесі : навч. посіб. Вінниця, 2011. 220 с.

8. Мадзігон В.В, Лапінський В.М, Дорошенко Ю.О. Педагогічні аспекти створення і використання електронних засобів навчання. Проблеми сучасного підручника. Київ : Педагогічна думка, 2003. Вип. 4. C. 70-81.

9. Олійник Ю.І. Формування творчої особистості майбутніх вчителів мистецьких спеціальностей засобами комп'ютерних технологій : автореф. дис. канд. пед. наук: 13.00.04. Київ, 2010. 20 с.

10. Петухова Л.Є., Бальоха А.С. Інсрормаційнокомунікаційне педагогічне середовище в контексті просресійної підготовки майбутніх вчителів початкової школи. Science and Education in New Dimension. Pedagogy and Psychology, IV (39), Issue: 79, 2016. P. 60-64 (ukr). URL: https://seanewdim.com/ uploads/3/4/5/1/34511564/ped_psy iv 39 79.pdf (дата звернення: 15.03.2020).

11. Про затвердження стандарту вищої освіти за спеціальністю 025 «Музичне мистецтво» для першого (бакалаврського) рівня вищої освіти : наказ Міністерства освіти і науки України від 24.05.2019 № 727. URL: https://mon.gov.ua/ua/npa/pro-zatverdzhennyastandartu-vishoyi-osviti-za-specialnistyu-025-muzichnemistectvo-dlya-pershogo-bakalavrskogo-rivnya-vishoyiosviti (дата звернення: 12.03.2020).

12. Рамський Ю.С. Формування інорормаційної культури особистості - пріоритетне завдання сучасної освітньої діяльності. Науковий часопис НПу імені М.П. Драгоманова. Серія № 2. Комп'ютерноорієнтовані системи навчання. 2004. № 1(8). C. $19-42$.

13. Управління інфрормаційними технологіями вищих навчальних закладів : навч. посіб. Вид 3-тє, допов / Співаковський О.В., Федорова Я.Б., Глущенко О.О., Кудас Н.А. Херсон : Айлант, 2010. $302 \mathrm{c}$

14. Чайковська О., Александрова Г. Мультимедійні технології як чинник формування інноваційного навчального середовища на уроках музики. Рідна школа. 2013. № 3. С. 66-69.

15. Чураков Д.Г. Развитие креативности у студентов музыкальных специальностей вуза с помощью музыкально-компьютерных технологий. Вектор науки ТГУ. 2012. № 1(8). С. 321-324. 